\title{
Effects of maternal iron restriction in the rat on hypoxia-induced gene expression and fetal metabolite levels
}

\author{
Rohan M. Lewis*, Lynwen A. James, Junlong Zhang, Christopher D. Byrne and C. Nicholas Hales \\ Department of Clinical Biochemistry, Addenbrooke's Hospital, University of Cambridge, Cambridge CB2 2QR, UK
}

(Received 10 April 2000 - Revised 18 August 2000 - Accepted 22 August 2000)

\begin{abstract}
The mechanism by which maternal Fe deficiency in the rat causes fetal growth retardation has not been clearly established. This study compared the effects on the fetuses from dams fed a control diet with two groups of dams fed Fe-restricted diets. One Fe-restricted group was fed the Fe-restricted diet for 1 week prior to mating and throughout gestation and the second $\mathrm{Fe}$ restricted group was fed the Fe-restricted diet for 2 weeks prior to mating and throughout gestation. On day 21 of gestation Fe-restricted dams, and their fetuses, were anaemic. Fetal weight was reduced in both Fe-restricted groups compared with controls. Expression of hypoxia-inducible factor (HIF)- $1 \alpha$ and vascular endothelial growth factor (VEGF) are induced by hypoxia. The levels of HIF- $1 \alpha$ mRNA were highest in placenta, then in kidney, heart and liver but were not different between the groups. Levels of plasma VEGF were not different between the groups. Maternal plasma triacylglycerol was decreased in the 1-week Fe-restricted dams compared with controls. Maternal plasma cholesterol and free fatty acid levels were not different between the groups. In fetal plasma, levels of triacylglycerol and cholesterol were decreased in both Fe-restricted groups. In maternal plasma, levels of a number of amino acids were elevated in both Fe-restricted groups. In contrast, levels of a number of amino acids in fetal plasma were lower in both Fe-restricted groups. Fetal plasma lactate was increased in Ferestricted fetuses but fetal plasma glucose and $\beta$-hydroxybutyrate were not affected. These changes in fetal metabolism may contribute to fetal growth retardation in this model. This study does not support the hypothesis that the Fe-restricted fetus is hypoxic.
\end{abstract}

Iron-deficiency anaemia: Fetal growth retardation: Fetal nutrition

Maternal anaemia is associated with an increased risk of intrauterine growth retardation in man (van den Broek, 1998; Zhou et al. 1998). Intrauterine growth retardation is clinically important as it is associated with increased perinatal morbidity and mortality (McCormick, 1985). Low birth weight is associated with increased rates of disease in adult life (Law \& Shiell, 1996).

A number of studies have demonstrated associations between maternal anaemia and low birth weight (Steer et al. 1995; Singla et al. 1997; Zhou et al. 1998). Some studies suggest that there are sensitive periods during gestation, such as in early gestation, when anaemia is most strongly associated with birth weight (Zhou et al. 1998).

$\mathrm{Fe}$ deficiency is a major cause of anaemia in man, although Fe deficiency is often also associated with broader nutritional deficiencies (Steer et al. 1995). In the rat, it is possible to generate Fe-deficiency anaemia using diets solely deficient in Fe. Maternal Fe deficiency in the rat causes maternal anaemia and fetal growth retardation (Shepard et al. 1980; Crowe et al. 1995). In addition there are long-term effects on the offspring of Fe-deficient dams, blood pressure has been found to be elevated (Crowe et al. 1995), and behavioural differences have been observed (Felt \& Lozoff, 1996).

The mechanism by which Fe-deficiency anaemia causes growth retardation has not been clearly established. One possibility is that the fetus becomes hypoxic due to maternal anaemia and reduced $\mathrm{O}_{2}$ availability to the fetus. Maternal hypoxia causes intrauterine growth retardation in the rat (Van Geijn et al. 1980; Lueder et al. 1995), as does increasing the $\mathrm{O}_{2}$ affinity of maternal haemoglobin (Hebbel et al. 1980). Alternatively, Fe-deficiency may cause growth retardation more directly by affecting the activity of the enzymes requiring Fe as a cofactor. Many of the enzymes involved in electron transport and oxidative metabolism require $\mathrm{Fe}$ as a cofactor. If normal metabolism

\footnotetext{
Abbreviations: HIF, hypoxia-inducible factor; PCR, polymerase chain reaction; VEGF, vascular endothelial growth factor.

* Corresponding author: Dr Rohan M. Lewis, present address Department of Obstetrics and Gynaecology, University of Southampton, Princess Ann Hospital, Coxford Road, Southampton SO16 5YA, UK, fax + 442380 786933, email rml2@soton.ac.uk
} 
was affected by $\mathrm{Fe}$ deficiency this could result in fetal growth retardation. Fe deficiency has been shown to alter phenylalanine levels in both the adult and fetal rat and to affect lipid metabolism (Mackler et al. 1979, 1983; Stangl \& Kirchgessner, 1998a). This indicates that Fe deficiency can disturb normal metabolism in the rat.

Hypoxia-inducible factor (HIF)- $1 \alpha$ is a transcription factor whose expression is induced by hypoxia in the rat (Wiener et al. 1996; Semenza et al. 1997; Bergeron et al. 1999; Jung et al. 2000). In the fetal sheep, anaemia has been shown to induce expression of HIF-1 $\alpha$ in heart tissue (Martin et al. 1998), suggesting that in the anaemic fetus $\mathrm{O}_{2}$ supply to fetal tissues is impaired.

Vascular endothelial growth factor (VEGF) mRNA levels are up-regulated by hypoxia (Goldberg \& Schneider, 1994 ) and the gene has a hypoxia response element in its promoter region (Forsythe et al. 1996).

Fetal growth is dependent upon the proper availability and metabolism of metabolic substrates. In this present study, substrate supply to the fetus was investigated in $\mathrm{Fe}$ restricted rats. HIF-1 $\alpha$ mRNA levels in fetal organs and VEGF protein in fetal plasma were measured as markers of fetal hypoxia and fetal lipids and amino acids, glucose and lactate were compared in fetal plasma.

\section{Methods \\ Animals and diets}

All animal procedures were performed, under licence, in accordance with the Scientific Procedures Act (1986). Prior to the study, rats were fed LAD-1 diet (Special Diet Services, Witham, Essex, UK). Virgin Wistar females were housed individually and maintained at $22^{\circ} \mathrm{C}$ fed either control (K4447.01) or low-Fe diets ad libitum (K4447.00; Hope Farms, Woerden, Holland) and provided with deionised water. The control diet was made by adding $150 \mathrm{mg} \mathrm{Fe} / \mathrm{kg}$ (as iron subcarbonate) to the Fe-deficient diet (Fe content $3 \mathrm{mg} / \mathrm{kg}$ ) at the time of manufacture. As such, the two experimental diets were identical apart from the differences in $\mathrm{Fe}$ content. The diets contained $175 \mathrm{~g}$ crude protein, $52 \mathrm{~g}$ crude fat, $662 \mathrm{~g}$ sugar and starch $/ \mathrm{kg}$ with a gross energy content of $4.03 \mathrm{MJ} / \mathrm{kg}$.

There were three groups in the study: control, 1-week Ferestricted and 2-week Fe-restricted. Controls were fed the control diet for $14 \mathrm{~d}$ prior to mating and throughout gestation. The 1-week Fe-restricted group were fed control diet for $7 \mathrm{~d}$ then switched to the Fe-restricted diet for $7 \mathrm{~d}$ before mating and continued on this diet throughout gestation. The 2-week Fe-restricted group were fed the Fe-deficient diet for $14 \mathrm{~d}$ prior to mating and throughout gestation. Mating was begun on day 15 of the experimental diet, animals were mated between 16.00 and 08.00 hours. Animals that did not mate within $4 \mathrm{~d}$ were excluded from the study. Day 1 of gestation was determined to be the day that a vaginal plug was observed.

\section{Sample collection}

Maternal blood (300-400 $\mu \mathrm{l})$ was collected for haematology from the tail vein on the first day of the experiment and 2 weeks later, on the day of mating.

On day 21 of gestation dams were anaesthetised with halothane and then killed by decapitation. Maternal trunk blood was collected in tubes containing EDTA and aprotinin (500 kIU/ml; ICN, Aurora, OH, USA). The uterus was removed and fetuses and placentas dissected out and weighed. Fetuses were decapitated and fetal trunk blood was collected using capillary tubes and pooled in tubes containing EDTA. An aliquot of whole blood was taken for haematological analysis and remaining blood was spun down, the plasma collected and stored at $-20^{\circ} \mathrm{C}$. Fetal hearts livers and kidneys were dissected out. The organs from the first five to six fetuses dissected were frozen in liquid N, remaining organs were weighed. Frozen tissues were then stored at $-70^{\circ} \mathrm{C}$.

\section{Blood counts}

Full blood counts on maternal and fetal blood were performed in the clinical laboratories of the Department of Haematology, Addenbrooke's Hospital, Cambridge.

\section{Preparation of total RNA}

Total RNA was extracted from fetal and placental tissues using a Quick Prep ${ }^{\mathrm{TM}}$ total RNA extraction Kit (Pharmacia Biotek, Peapack, NJ, USA) according to the manufacturer's instructions. RNA was quantified by spectrophotometry. The integrity of the RNA was assessed by examination of $28 \mathrm{~s}$ and $18 \mathrm{~s}$ bands following gel electrophoresis.

\section{Quantitative reverse-transcriptase polymerase chain reaction}

Quantitative competitive reverse-transcriptase polymerase chain reaction (PCR) was performed, with slight modification, from the method described by Zhang \& Byrne (1997). Briefly, three primers were designed for the HIF- $1 \alpha$ gene using sequence published in genebank (accession number Y09507) from position 1190 to 2378 on this clone: a sense primer (primer 1, incorporating $\mathrm{T} 7$ promoter at the $5^{\prime}$ end) 5'-TAA TAC GAC TCA CTA TAG GGG AAT CAA AAG CAG TGA CGA AG-3'), an anti-sense primer (primer 5, $5^{\prime}$-TTC CAA GAA AGC GAC ATA GTA-3') and an internal anti-sense primer (primer 3, incorporating primer 5 at the $5^{\prime}$ end, 5'-TTC CAA GAA AGC GAC ATA GTA TTC CTC TGA GCA TTC TGC AAA-3'). Primer 1 contained the $\mathrm{T} 7$ promoter so that the product included the T7 promoter at the $5^{\prime}$ end. Primer 3 included P5 at its $5^{\prime}$ end so that the product of primer 1 and primer 3 was a DNA sequence identical to the product of primer 1 and primer 5 except that 81 base pairs were deleted internally. RNA was then synthesised from the DNA product amplified with primer 1 and primer 3, using T7 RNA polymerase and the resulting RNA was purified. The standard RNA was then quantified and known amounts were spiked into total RNA samples before quantitative reverse-transcriptase PCR was undertaken. Following reverse-transcriptase PCR a 409 base pairs band from the target RNA was amplified and a 
shorter 328 base pairs band from the standard RNA which were separated by agarose gel electrophoresis.

The target RNA was reverse transcribed with four different concentrations of standard RNA to ensure that the reverse transcription reaction was equally efficient for both the target RNA and standard RNA. The cDNA was amplified for three different cycle numbers (twenty, twenty-one and twenty-two cycles) to ensure that the amplification was taking place in the exponential part of the curve for both standard and target RNA. This allowed an assessment to be made of how closely the criteria for quantitative reverse-transcriptase PCR were being met. Samples which did not meet the criteria established by Zhang \& Byrne (1997) were repeated. To test the reproducibility in the assay one sample was assayed on five different occasions and the intra-assay CV was $9.5 \%$.

\section{Standard RNA synthesis}

Total RNA $(1 \mu \mathrm{g})$ was transcribed into cDNA (as described later) using primer 5 to prime the reverse transcriptase. The cDNA was then amplified by PCR using primers 1 and 3 for twenty-two cycles. The product of this reaction was extracted with chloroform-isoamylalcohol $(24: 1, \mathrm{v} / \mathrm{v})$ and precipitated with $100 \%$ ethanol. The purified DNA was then transcribed into RNA using 10 units T7 ploymerase (Promega, Madison, WI, USA), $10 \mathrm{nmol}$ rNTPs (Promega), 10 units RNAsin (Promega) in T7 polymerase buffer (Promega) and incubating at $37^{\circ} \mathrm{C}$ for $1 \mathrm{~h}$. Template DNA was then digested by incubating with 100 units RNase-free DNase (Boehringer Mannheim, Mannheim, Germany) for $1 \mathrm{~h}$. The standard RNA was extracted with chloroformisoamylalcohol $(24: 1, \mathrm{v} / \mathrm{v})$ and precipitated with $100 \%$ ethanol. The purified standard RNA was resuspended in RNA storage buffer, $1 \mathrm{mM}$-sodium citrate $\mathrm{pH} 6.4$ (Ambion, Austin, TX, USA). PCR was performed on a sample of the standard RNA for thirty cycles and the product run out on an agarose gel. If no bands appeared from the sRNA samples it was considered to be free from contamination by DNA template. A sample of the standard RNA was then quantified by spectrophotometry.

\section{cDNA synthesis}

The RNA was denatured at $70^{\circ} \mathrm{C}$ for $5 \mathrm{~min}$ and then cooled to $4^{\circ} \mathrm{C}$. The following reagents were added; $10 \mathrm{nmol}$ dNTP mix (Promega), 80 pmol primer 5, 100 units MMLV reverse transcriptase, 10 units RNAsin (Promega), 5× MMLV reverse transcriptase buffer (Promega) and water to make a final volume of $20 \mu \mathrm{l}$. The reaction was incubated for $1 \mathrm{~h}$ at $42^{\circ} \mathrm{C}$ and $5 \mathrm{~min}$ at $95^{\circ} \mathrm{C}$.

\section{Polymerase chain reaction}

PCR amplification was performed using Ready to Go PCR beads (Amersham Pharmacia, Piscataway, NJ, USA). The reaction volume was $25 \mu \mathrm{l}$, with $1 \mu \mathrm{l}$ cDNA and $24 \mu \mathrm{l}$ water containing $10 \mathrm{pmol}$ each of primer 1 and primer 5 . The reaction was heated to $95^{\circ} \mathrm{C}$ for $5 \mathrm{~min}$ and then each cycle of amplification consisted of 1 min of denaturation at $95^{\circ} \mathrm{C}, 50 \mathrm{~s}$ for annealing at $60^{\circ} \mathrm{C}$ and $1 \mathrm{~min}$ for extension at $72^{\circ} \mathrm{C}$. Amplification was carried out for twenty to twentytwo cycles.

\section{Vascular endothelial growth factor}

Fetal plasma VEGF was measured using a murine VEGF ELISA kit (R\&D Systems, Minneapolis, MN, USA). This kit uses two polyclonal antibodies to mouse VEGF, with which there is a $98 \%$ amino-acid sequence homology to rat VEGF. When fetal rat plasma was serially diluted a linear response was obtained and the values obtained did not vary by more than $20 \%$ from the expected values. Fetal rat plasma was diluted two-fold in assay buffer and each sample was assayed in duplicate.

\section{Amino acid analysis}

Plasma amino acid levels were analysed in clinical laboratories using a Biochrom 20 amino acid analyser (Pharmacia Biotech). This system uses ion-exchange chromatography with ninhydrin detection. Tryptophan and cystine are not measured in this system. When the fetal plasma samples were measured there was a technical problem, which meant that fetal plasma arginine concentrations were not measured. As $150 \mu \mathrm{l}$ plasma was required for this assay it was not possible to measure amino acids for all of the fetal samples.

Plasma lipids were measured using enzymatic assays run on a Monarch auto-analyser (Instrumentation Laboratories, Lexington, MA, USA). Free fatty acids were measured using the Free Fatty Acids, Half-micro test, (Boheringer Mannheim, catalogue no. 1383 175). Plasma triacylglycerol was measured using GPO Trinder reagents (Sigma Diagnostics, St Louis, MO, USA, catalogue no. 337-A). Cholesterol was measured using Infinity cholesterol reagent (Sigma Diagnostics, catalogue no. 401-25P).

Fetal plasma glucose and lactate were measured in an auto-analyser.

Fetal plasma $\beta$-hydroxybutyrate was measured using an enzymatic assay (Sigma Diagnostics, catalogue no. 310-A) run on a Monarch auto-analyser (Instrumentation Laboratories).

\section{Statistical analysis}

As members of the same litter cannot be regarded as independent, where multiple members of the same litter were included in the data (fetal weights, placental weights and fetal organ weights) the analysis was performed using a linear mixed effects model with litter included as a random effect. These analyses were performed using the statistical package S Plus (version 4.5; Math Soft Inc., Cambridge, MA, USA).

Where multiple members of the same litter were not included in the data, ANOVA was used to determine whether there were differences between the three groups. Where significance was indicated, differences between individual groups were determined by using the Bonferroni correction. In some cases, where the data was abnormally distributed, the analysis was performed on ranked data.

Where the control group was compared with the 
Table 1. Maternal weights, litter sizes, fetal body weight and fetal organ weights in control and iron-restricted groups $†$ (Mean values and standard deviations)

\begin{tabular}{|c|c|c|c|c|c|c|}
\hline & \multicolumn{2}{|c|}{ Control $(n 6)$} & \multicolumn{2}{|c|}{ 1-week ( $n 7)$} & \multicolumn{2}{|c|}{ 2-week (n 7) } \\
\hline & Mean & SD & Mean & SD & Mean & SD \\
\hline Maternal weight on day 1 (g) & 253 & 16 & 239 & 17 & 236 & 15 \\
\hline Maternal weight on day $21(\mathrm{~g})$ & 436 & 32 & $378^{\star \star}$ & 34 & $372^{\star \star}$ & 23 \\
\hline Average daily maternal food intake during gestation (g) & $25 \cdot 6$ & $2 \cdot 6$ & $21 \cdot 4^{\star *}$ & $1 \cdot 6$ & $21 \cdot 5^{\star *}$ & $1 \cdot 8$ \\
\hline Litter size $(n)$ & $15 \cdot 17$ & 1.72 & $8 \cdot 7^{\star \star}$ & $2 \cdot 4$ & $10^{\star \star}$ & $3 \cdot 8$ \\
\hline Reabsorbtions $(n)$ & $0 \cdot 17$ & 0.41 & $4 \cdot 2^{\star \star}$ & $2 \cdot 4$ & $2 \cdot 1$ & $2 \cdot 9$ \\
\hline Fetal weight $(\mathrm{g})$ & 3.83 & 0.17 & $3 \cdot 1^{\star * *}$ & 0.56 & $3.4^{\star * \star}$ & 0.3 \\
\hline Placental weight $(\mathrm{g})$ & 0.47 & 0.03 & 0.49 & 0.03 & $0.52^{\star}$ & 0.04 \\
\hline Placental wt/fetal wt (\%) & $12 \cdot 27$ & 0.56 & $16 \cdot 2^{\star \star \star}$ & $2 \cdot 6$ & $15 \cdot 4^{\star \star \star}$ & 2.4 \\
\hline Heart wt/fetal wt (\%) & 0.52 & 0.04 & $0.65^{\star \star \star}$ & $0 \cdot 11$ & $0.63^{\star \star *}$ & 0.08 \\
\hline Liver wt/fetal wt (\%) & $7 \cdot 84$ & 0.54 & $5 \cdot 95^{\star *}$ & 0.85 & $6 \cdot 3^{\star \star}$ & 0.6 \\
\hline Kidney wt/fetal wt (\%) & 0.69 & 0.06 & 0.71 & 0.08 & 0.71 & 0.06 \\
\hline
\end{tabular}

Mean values were significantly different from control group: ${ }^{\star} P<0.05,{ }^{\star \star} P<0.01,{ }^{\star \star \star} P<0.005$.

† For details of diets and procedures see p. 194.

combined Fe-restricted groups, data was analysed by unpaired $t$ test. Unless otherwise stated, data is presented as mean values and standard deviations. Significance was assumed at $P<0 \cdot 05$. Statistical analyses were performed using SPSS version 8 (SPSS Inc., Chicago, IL, USA).

\section{Results}

Days on the experimental diets before mating were for the control group 16.7 (SD 1.0) d, for the 1-week Fe-restricted group days 15.67 (SD 0.7) (8.67 (SD 0.7) on the low-Fe diet) and for the 2-week group 16.3 (SD 1.2) d.
There were no differences in maternal weight on the first day of pregnancy. On day 21 of gestation both the 1 and 2week Fe-restricted groups were lighter than controls $(P<0 \cdot 01$, Table 1$)$. The 2 -week Fe-restricted dams were lighter than controls from day 19 of gestation $(P<0.05)$. The 1-week Fe-restricted dams were lighter than controls from day 20 of gestation $(P<0.05)$. There were no differences in total food intake in the 2 weeks before pregnancy (data not shown). Average daily food intake during gestation was lower in both Fe-restricted groups compared with control $(P<0.01$, Table 1$)$.

Maternal red cell count, haemoglobin and haematocrit

Table 2. Maternal haematology in control and iron-restricted dams $\ddagger$

(Mean values and standard deviations)

\begin{tabular}{|c|c|c|c|c|c|c|}
\hline & \multicolumn{2}{|c|}{ Control (n 6) } & \multicolumn{2}{|c|}{ 1-week (n 7) } & \multicolumn{2}{|c|}{ 2-week (n 6) } \\
\hline & Mean & SD & Mean & SD & Mean & SD \\
\hline \multicolumn{7}{|c|}{ Red cell count $\left(10^{9} / \mathrm{l}\right)$} \\
\hline Initial & $6 \cdot 7$ & 0.4 & $6 \cdot 6$ & 0.6 & $6 \cdot 9$ & 0.4 \\
\hline Mating & $7 \cdot 2$ & 0.4 & $6 \cdot 9$ & 0.4 & $7 \cdot 0$ & $0 \cdot 2$ \\
\hline Day 21 & $5 \cdot 4$ & 0.4 & 3.6 & $0.7^{\star \star}$ & 3.7 & $0.7^{\star *}$ \\
\hline Fetal day 21 & 1.72 & 0.17 & $1 \cdot 15$ & $0.31^{*}$ & $1 \cdot 36$ & 0.34 \\
\hline \multicolumn{7}{|c|}{ Haemoglobin $(\mathrm{g} / \mathrm{l})$} \\
\hline Initial & 145 & 7 & 145 & 11 & 147 & 6 \\
\hline Mating & 149 & 6 & 145 & 10 & 136 & 15 \\
\hline Day 21 & 104 & 5 & $69^{\star \star \star}$ & 11 & $68^{\star \star \star}$ & 12 \\
\hline Fetal day 21 & 98.5 & $6 \cdot 3$ & $47 \cdot 2^{\star \star \star}$ & $9 \cdot 3$ & $42^{\star \star \star}$ & 8.9 \\
\hline \multicolumn{7}{|c|}{ Mean cell volume ( $\mu \mathrm{m} 3)$} \\
\hline Initial & $65 \cdot 8$ & $4 \cdot 1$ & $65 \cdot 3$ & $3 \cdot 4$ & 65.4 & $4 \cdot 1$ \\
\hline Mating & $60 \cdot 6$ & 2.4 & $56 \cdot 6$ & 11.4 & $60 \cdot 0$ & $2 \cdot 7$ \\
\hline Day 21 & 55.4 & 1.5 & $51 \cdot 7^{\star *}$ & 1.6 & $49 \cdot 3^{\star \star} \dagger$ & 1.6 \\
\hline Fetal day 21 & 173 & 12 & $121^{\star \star \star}$ & 13 & $110^{\star \star \star}$ & 11 \\
\hline \multicolumn{7}{|c|}{ Red cell distribution width } \\
\hline Initial & $13 \cdot 5$ & $1 \cdot 1$ & $13 \cdot 5$ & 0.8 & $13 \cdot 5$ & 1.0 \\
\hline Mating & $12 \cdot 9$ & 0.2 & $15 \cdot 6$ & $3 \cdot 2$ & $17 \cdot 1^{\star}$ & $3 \cdot 2$ \\
\hline Fetal day 21 & $28 \cdot 5$ & 1.6 & 30.4 & $2 \cdot 3$ & $27 \cdot 3$ & 2.9 \\
\hline Day 21 & $12 \cdot 9$ & 0.7 & $22 \cdot 1^{\star \star}$ & $3 \cdot 8$ & $22 \cdot 9^{\star \star}$ & $3 \cdot 8$ \\
\hline \multicolumn{7}{|l|}{ Haematocrit (\%) } \\
\hline Initial & 0.44 & 0.03 & 0.43 & 0.04 & 0.45 & 0.03 \\
\hline Mating & 0.44 & 0.04 & 0.43 & 0.04 & 0.42 & 0.03 \\
\hline Day 21 & 0.30 & 0.02 & $0.18^{\star \star \star}$ & 0.04 & $0.18^{\star \star \star}$ & 0.04 \\
\hline Fetal day 21 & $0 \cdot 30$ & 0.02 & $0 \cdot 14^{\star * *}$ & 0.04 & $0.15^{\star * \star}$ & 0.03 \\
\hline
\end{tabular}

Mean values were significantly different from those of the control group: ${ }^{\star} P<0.05,{ }^{\star \star} P<0.005,{ }^{\star \star \star} P<0.001$.

Mean value was significantly different from 1-week Fe restricted group: $\dagger P<0.05$.

$\ddagger$ For details of diets and procedures see p. 194. 


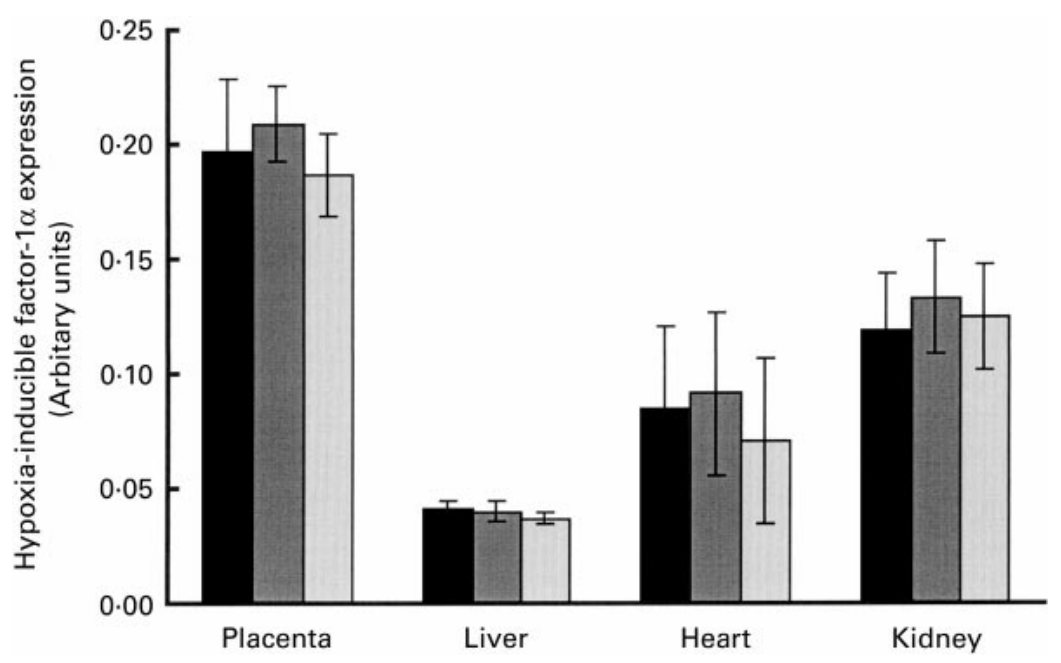

Fig. 1. Hypoxia-inducible factor-1 $\alpha$ expression in the placenta, heart and kidneys of control ( $\square)$, 1-week Fe-restricted $(\square)$ and 2-week Fe-restricted ( $\square$ ) litters on day 21 of gestation. Values are means with standard deviations represented by vertical bars $(n$ 5-6 samples were analysed for each group in each organ except for the 2-week placenta group where $n 4$ ). For details of diets and procedures see p. 194. There was no significant difference between the mean levels of each group, but the mean mRNA levels in the different organs were all significantly different $(P<0.01)$.

were not different between the groups at the beginning of the study or at mating. On day 21 of gestation these were reduced in the Fe-restricted groups $(P<0 \cdot 001$, Table 2$)$. There were no differences in these variables between the two Fe-restricted groups. Maternal mean cell volume was not different between the two groups at the beginning of the study, or at mating, but was reduced in both Fe-restricted groups $v$. control $(P<0 \cdot 002$, Table 2$)$. Mean cell volume was also reduced in the 2-week Fe-restricted group $v$. the 1week Fe-restricted group $(P=0 \cdot 048$, Table 2$)$. Red cell distribution width, which indicates a normally-balanced red cell population, was not different between the groups on day 1 of the study. At mating, red cell distribution width had begun to be elevated in the Fe-restricted groups, although this was only significant in the 2-week $\mathrm{Fe}$ restricted group $(P=0<050)$. On day 21 of gestation maternal red cell distribution width was elevated in both Fe-restricted groups $(P<0.002$, Table 2$)$

Fetal weight was decreased in both Fe-restricted groups compared with the control group $(P<0 \cdot 01$, Table 1$)$ but there was no difference between the 1 and 2-week Ferestricted groups.

Litter size was decreased in both 1 and 2-week Ferestricted groups compared with control $(P<0.05$ and $P<$ 0.005 respectively, Table 1$)$ but there was no significant difference in litter size between the Fe-restricted groups.

There were more reabsorptions in the 1 -week $\mathrm{Fe}$ restricted group compared with control group $(P<0.001$, Table 1), but there was no significant difference between control and 2-week Fe-restricted groups.

There was a small increase in placental weight in the 2week Fe-restricted group compared with control $(P<0.05$, Table 1). However, there were no differences in placental weight between control and 1-week Fe-restricted or between the 1 and 2-week Fe-restricted groups. Placental weight was increased as a proportion of fetal body weight in both Fe-restricted groups $(P<0 \cdot 002$, Table 1$)$.

Fetal heart weight, as a percentage of fetal body weight, was increased in both Fe-restricted groups compared with the control group $(P<0.01$, Table 1$)$. Liver weight, as a percentage of fetal body weight, was decreased in both Fe-restricted groups compared with the control group $(P<0.005$, Table 1$)$. There were no differences in kidney weight as a percentage of body weight between the groups.

On day 21 of gestation, fetal haemoglobin, haematocrit and mean red cell volume were decreased in both the Ferestricted groups compared with the control group $(P<$ $0 \cdot 001$, Table 2). Fetal red cell count was decreased in both Fe-restricted groups but this was only significant in the 1week Fe-restricted group $(P<0 \cdot 01)$. Fetal red cell distribution width was not different between the groups.

There were no significant differences in HIF- $1 \alpha$ mRNA levels between the groups in the fetal liver, heart, kidney or in the placenta (Fig. 1). HIF-1 $\alpha$ mRNA levels were different in the different organs. The highest level of HIF- $1 \alpha$ expression was in the placenta. Within the fetus the highest level of HIF-1 $\alpha$ was in the kidney, then the heart and lowest the liver $(P<0.001$, Fig. 1$)$.

There were no significant differences in fetal plasma VEGF levels between the groups. VEGF levels in the control group were 59.0 (SD 10.0) $\mathrm{pg} / \mathrm{ml}$, in the 1-week Ferestricted group 63.8 (SD 13.3) pg/ml and in the 2-week Ferestricted group 66.6 (SD 9.8) $\mathrm{pg} / \mathrm{ml}$. One value from the 1week Fe-restricted group was 26 SD greater than the next highest value and was not included in the analysis.

Levels of free fatty acids and cholesterol in maternal plasma were not different between the groups. Maternal triacylglycerol was decreased in the 1-week Fe-restricted group compared with the control group $(P<0.05)$ but the 
Table 3. Maternal and fetal plasma lipids in control and Fe-restricted dams†

\begin{tabular}{|c|c|c|c|c|c|c|c|c|c|c|c|c|}
\hline & \multicolumn{6}{|c|}{ Maternal plasma } & \multicolumn{6}{|c|}{ Fetal plasma } \\
\hline & \multicolumn{2}{|c|}{ Control $(n 6)$} & \multicolumn{2}{|c|}{ 1-week ( $n 7)$} & \multicolumn{2}{|c|}{ 2-week (n 6) } & \multicolumn{2}{|c|}{ Control $(n 6)$} & \multicolumn{2}{|c|}{ 1-week (n 5) } & \multicolumn{2}{|c|}{ 2-week (n 6) } \\
\hline & Median & $\begin{array}{l}\text { Interquartile } \\
\text { range }\end{array}$ & Median & $\begin{array}{l}\text { Interquartile } \\
\text { range }\end{array}$ & Median & $\begin{array}{l}\text { Interquartile } \\
\text { range }\end{array}$ & Mean & SD & Mean & SD & Mean & SD \\
\hline Triacylglycerol (mmol/l) & 4.81 & $3 \cdot 53-6 \cdot 31$ & $2.49^{*}$ & $2 \cdot 18-2.91$ & 3.07 & $1.02-4.90$ & 0.53 & 0.11 & $0.37^{\star}$ & $0 \cdot 10$ & $0.38^{*}$ & 0.06 \\
\hline Cholesterol $(\mathrm{mmol} / \mathrm{l})$ & 2.90 & $2 \cdot 70-3 \cdot 15$ & 2.90 & $2.55-3.03$ & 2.55 & $2 \cdot 16-2 \cdot 64$ & 2.05 & 0.36 & $1 \cdot 39^{\star \star}$ & 0.24 & $1 \cdot 34^{\star \star}$ & 0.16 \\
\hline Free fatty acids $(\mu \mathrm{mol} / \mathrm{l})$ & 297 & $227-519$ & 227 & $146-487$ & 237 & $150-482$ & 162 & 15 & 140 & 36 & 159 & 20 \\
\hline
\end{tabular}

Values were significantly different from those of the control group: ${ }^{*} P<0.05,{ }^{* \star} P<0.005$.

† For details of diets and procedures see. p. 194.

2-week Fe-restricted group was not significantly different from the control group (Table 3).

Fetal plasma triacylglycerol levels were decreased in both Fe-restricted groups $(P<0 \cdot 04$, Table 2$)$. Fetal plasma cholesterol was decreased in both Fe-restricted groups $(P<0 \cdot 005$, Table 3$)$. Levels of free fatty acid levels in fetal plasma were not different between the groups (Table 3).

Maternal plasma amino acid levels were lower than fetal plasma values. Maternal plasma levels of amino acids tended to be higher in the Fe-restricted groups (Table 4).

Fetal plasma amino acids, with the exception of alanine and glutamate, tended to be lower in the Fe-restricted groups compared with the control group (Table 5). Citrulline, which is an intermediate in the urea cycle, was not detected in fetal plasma.

As there was a limited supply of fetal plasma for glucose lactate and $\beta$-hydroxybutyrate there was only enough sample to analyse: control $n 5$, 1-week $n 3$ and 2-week $n$ 4. As the numbers were small, data for these metabolites

Table 4. Maternal plasma amino acids ( $\mu \mathrm{mol} / \mathrm{l})$ in control and Ferestricted damst

(Mean values and standard deviations)

\begin{tabular}{|c|c|c|c|c|c|c|}
\hline & \multicolumn{2}{|c|}{ Control $(n 6)$} & \multicolumn{2}{|c|}{ 1-week (n 7) } & \multicolumn{2}{|c|}{ 2-week (n 6) } \\
\hline & Mean & SD & Mean & SD & Mean & SD \\
\hline Taurine & $113 \cdot 7$ & $13 \cdot 4$ & $173 \cdot 0^{\star \star}$ & $33 \cdot 3$ & $167 \cdot 1^{\star \star}$ & $70 \cdot 8$ \\
\hline Aspartate & & $4 \cdot 8$ & $22 \cdot 9^{\star \star}$ & $5 \cdot 0$ & $23 \cdot 5^{\star}$ & 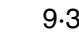 \\
\hline Threonine & $525 \cdot 5$ & $156 \cdot 1$ & 692.4 & $164 \cdot 6$ & $562 \cdot 7$ & 108 \\
\hline Serine & 253.5 & 58.7 & $322 \cdot 0$ & 54.1 & $336 \cdot 1$ & 80 \\
\hline Glutamate & $160 \cdot 7$ & $62 \cdot 0$ & $208 \cdot 0$ & $63 \cdot 3$ & $216 \cdot 5$ & $79 \cdot 1$ \\
\hline Glutamine & 542.5 & 48.9 & $685 \cdot 7^{\star \star \star}$ & $71 \cdot 8$ & $745 \cdot 9^{\star \star *}$ & $76 \cdot 3$ \\
\hline Proline & 379.3 & $102 \cdot 9$ & 476.6 & $74 \cdot 1$ & $499 \cdot 6^{\star}$ & $127 \cdot 1$ \\
\hline Glyci & 57.5 & $6 \cdot 1$ & & 9.9 & $67 \cdot 8$ & $18 \cdot 7$ \\
\hline Alanine & 739.0 & $202 \cdot 0$ & $1050 \cdot 6$ & $126 \cdot 4$ & $1333 \cdot 0^{\star *}$ & 371.5 \\
\hline Citrulline & $66 \cdot 0$ & $12 \cdot 7$ & $64 \cdot 3$ & $13 \cdot 0$ & $59 \cdot 2$ & $10 \cdot 3$ \\
\hline Valine & $167 \cdot 0$ & $51 \cdot 3$ & 238.6 & $49 \cdot 4$ & $239 \cdot 0$ & $75 \cdot 0$ \\
\hline onine & 67.5 & $15 \cdot 2$ & 82 & $12 \cdot 2$ & $92 \cdot 6^{*}$ & 16 . \\
\hline Isolet & $75 \cdot 8$ & 24.6 & 96.9 & $19 \cdot 1$ & $96 \cdot 0$ & 28 \\
\hline Leucine & $110 \cdot 0$ & 39.2 & $169 \cdot 0$ & $36 \cdot 8$ & 167.4 & $57 \cdot 6$ \\
\hline Tyrosine & $59 \cdot 0$ & $18 \cdot 4$ & 65.9 & $15 \cdot 0$ & 68.7 & $16 \cdot 7$ \\
\hline Phenylalanine & $61 \cdot 8$ & $16 \cdot 4$ & 74.4 & $14 \cdot 6$ & $75 \cdot 9$ & $17 \cdot 2$ \\
\hline Ornithine & $32 \cdot 0$ & $7 \cdot 6$ & & $5 \cdot 6$ & $34 \cdot 1$ & $7 \cdot 7$ \\
\hline Lysin & $816 \cdot 0$ & $95 \cdot 3$ & $1058 \cdot 3^{\star}$ & $149 \cdot 8$ & $1050 \cdot 9^{\star *}$ & 207.9 \\
\hline Histidine & $41 \cdot 2$ & $13 \cdot 5$ & $69 \cdot 1^{*}$ & 14.4 & $67 \cdot 8^{\star}$ & 17.6 \\
\hline Arginine & $69 \cdot 3$ & $8 \cdot 0$ & $97 \cdot 3^{*}$ & $15 \cdot 1$ & $97 \cdot 8$ & $28 \cdot 1$ \\
\hline
\end{tabular}

Mean values were significantly different from those of the control group:

${ }^{\star} P<0.05,{ }^{\star \star} P<0.01,{ }^{\star \star \star} P<0.005$

† For details of diets and procedures see p. 194. analysed using unpaired $t$-test as control $v$. combined $\mathrm{Fe}$ restricted groups. Fetal plasma glucose was not different between the control group $(2.70(2 \cdot 10-2.95)) v$. the combined Fe-restricted group (2.10 (1.90-3.00)). Fetal lactate was significantly higher in the combined $\mathrm{Fe}$ restricted groups than in the control group (11.74 (SD 1.97 v. $13.7 \mathrm{mmol} / \mathrm{l}$ (SD $1.06, P=0.049$ ). Fetal plasma $\beta$ hydroxybutyrate levels were not different between the groups (23.04 (SD 3.84) $\mu \mathrm{mol} / \mathrm{l}$ in the control v. 24.96 (SD 6.72) $\mu \mathrm{mol} / \mathrm{l}$ in the combined maternal Fe-restricted).

\section{Discussion}

This study found that maternal $\mathrm{Fe}$ restriction caused significant alterations both in maternal and fetal lipids and amino acids. It also demonstrated that there were significant tissue variations in the levels of HIF- $1 \alpha$ mRNA. However, despite severe maternal and fetal Fe-deficiency anaemia levels of fetal HIF- $1 \alpha$ mRNA and fetal plasma VEGF were not elevated in Fe-restricted fetuses. These

Table 5. Fetal plasma amino acids $(\mu \mathrm{mol} / \mathrm{l})$ in control and $\mathrm{Fe}$ restricted litters $\ddagger$

(Mean values and standard deviations)

\begin{tabular}{|c|c|c|c|c|c|c|}
\hline & \multicolumn{2}{|c|}{ Control (n 6) } & \multicolumn{2}{|c|}{ 1-week $(n 5)$} & \multicolumn{2}{|c|}{ 2-week (n 4) } \\
\hline & Mean & SD & Mean & SD & Mean & SD \\
\hline Taurine & $801 \cdot 7$ & $98 \cdot 2$ & $618 \cdot 8^{*}$ & 129.4 & $537 \cdot 3^{\star \star}$ & $46 \cdot 4$ \\
\hline Aspartate & $66 \cdot 8$ & $21 \cdot 1$ & $49 \cdot 0$ & 11.5 & $58 \cdot 8$ & 4.1 \\
\hline Threonine & 806.5 & $192 \cdot 3$ & 695.4 & $122 \cdot 6$ & 545.0 & $72 \cdot 4$ \\
\hline Serine & 443.0 & 69.8 & 392.0 & 62.5 & $383 \cdot 3$ & 23.5 \\
\hline Glutamate & $477 \cdot 2$ & $92 \cdot 6$ & 488.4 & 184.4 & $376 \cdot 8$ & 63.9 \\
\hline Glutamine & $1192 \cdot 7$ & 70.5 & $1130 \cdot 2$ & $68 \cdot 3$ & $1290 \cdot 5 \dagger$ & $42 \cdot 8$ \\
\hline Proline & $946 \cdot 7$ & $203 \cdot 6$ & $660 \cdot 0$ & 170.5 & $629 \cdot 0^{*}$ & 31.5 \\
\hline Glycine & 294.8 & $18 \cdot 1$ & 273.6 & 30.6 & 263.3 & 37.9 \\
\hline Alanine & $1684 \cdot 0$ & $248 \cdot 2$ & $1848 \cdot 0$ & 63.5 & $2182 \cdot 3^{\star \star}$ & $147 \cdot 8$ \\
\hline Valine & $521 \cdot 7$ & $97 \cdot 7$ & 483.8 & 65.9 & $448 \cdot 8$ & 41.7 \\
\hline Methionine & 233.0 & $35 \cdot 6$ & $165 \cdot 8^{*}$ & 21.6 & 178.3 & 34.5 \\
\hline Isoleucine & 169.5 & 38.3 & $163 \cdot 8$ & $16 \cdot 6$ & $161 \cdot 8$ & $13 \cdot 4$ \\
\hline Leucine & $315 \cdot 7$ & 74.4 & $348 \cdot 4$ & 39.3 & 324.0 & $19 \cdot 0$ \\
\hline Tyrosine & $277 \cdot 3$ & $42 \cdot 1$ & $173 \cdot 2^{\star \star}$ & $30 \cdot 4$ & $185 \cdot 3^{\star *}$ & $15 \cdot 6$ \\
\hline Phenylalanine & 293.5 & $29 \cdot 1$ & $209 \cdot 2^{\star \star}$ & $20 \cdot 8$ & $197 \cdot 0^{\star \star}$ & $17 \cdot 4$ \\
\hline Ornithine & 85.5 & $25 \cdot 0$ & $79 \cdot 2$ & $10 \cdot 8$ & 54.5 & 8.0 \\
\hline Lysine & $1700 \cdot 7$ & 209.9 & $1581 \cdot 2$ & 71.6 & $1630 \cdot 3$ & 234.1 \\
\hline Histidine & $95 \cdot 7$ & 38.3 & 82.4 & 19.9 & 67.5 & 8.5 \\
\hline
\end{tabular}

Mean values were significantly different from those of the control group: ${ }^{*} P<0.05,{ }^{* *} P<0.005$

Mean value was significantly different from that of the control group: $+P<0.01$

‡ For details of diets and procedures see p. 194 
findings raise the questions as to whether these fetuses were hypoxic and why they were growth retarded.

Fetal growth was reduced in both Fe-restricted groups compared with the controls. The effect in the 1-week group was as severe, if not more severe, than in the 2-week Ferestricted group. Although there was no significant difference in fetal weight between the two Fe-restricted groups, the 1-week Fe-restricted group had a lower mean weight and a significantly greater number of reabsorptions than in the two-week Fe-restricted group. It is possible that in the 2-week Fe-restricted group there was a degree of adaptation to the low-Fe environment preventing further growth restriction. An indication of this may be the increase in placental weight seen in the 2-week Ferestricted group. Although the increase in placental weight was small, it may reflect underlying changes in placental structure and function that act to maintain fetal weight.

HIF-1 $\alpha$ mRNA levels have been shown to be increased by hypoxia in the rat both in vivo and in vitro (Wiener et al. 1996; Jung et al. 2000; Bergeron et al. 1999). So the absence of any increase in HIF- $1 \alpha$ mRNA levels in the Ferestricted rat fetus does not support the hypothesis that fetal growth retardation following maternal Fe restriction is caused by anaemic hypoxia. Although we cannot know whether these fetuses were hypoxic without measuring $\mathrm{O}_{2}$ tension directly the HIF- $1 \alpha$ data combined with the VEGF data do suggest that the Fe-restricted fetus is not hypoxic. HIF-1 $\alpha$ mRNA levels in the rat have been found to be increased in vivo by short periods of hypoxia in the kidney but not the heart (Wiener et al. 1996). Longer periods of hypoxia increase HIF-1 $\alpha$ mRNA levels in the heart (Jung et al. 2000). Although no studies have investigated the effects of hypoxia on HIF- $1 \alpha$ in the fetal rat, HIF- $1 \alpha$ mRNA levels have been found to be increased by hypoxia in cultured neonatal rat cardiomyocytes suggesting that hypoxic induction of HIF- $1 \alpha$ expression is functional early in life.

A number of the changes that were observed in the $\mathrm{Fe}$ restricted fetuses could be interpreted as compensatory adaptations to cope with low $\mathrm{O}_{2}$ supply. The rat fetuses from Fe-restricted litters had a decreased fetal:placental weight ratio, which may allow proportionately greater transport of $\mathrm{O}_{2}$ to the fetus. Increased fetal heart weight: body weight may reflect cardiovascular adaptations which increase cardiac output and so increase the transfer of $\mathrm{O}_{2}$ across the placenta, a process which is flow limited (Doughty \& Sibley, 1995). In the sheep fetus heart weight and cardiac output have been shown to be increased by anaemia (Davis \& Hohimer, 1991).

In the near-term fetal sheep, increased cardiac HIF- $1 \alpha$ expression was observed in response to $10 \mathrm{~d}$ anaemia (Martin et al. 1998). This increase in HIF-1 $\alpha$ expression may not be seen in the rat fetus because it had developed in an Fe-restricted environment throughout gestation and has adapted to it. In the sheep, however, the fetus had developed in a normal environment for the majority of gestation and was then exposed to anaemia for which it was not prepared (Martin et al. 1998).

It could be argued that in prolonged hypoxia HIF-1 $\alpha$ mRNA levels do not remain elevated and that this is why HIF- $1 \alpha$ was not elevated in this study. While this is possible, cardiac HIF-1 $\alpha$ mRNA levels have been shown to be elevated in rats kept hypoxic for 3 weeks (Jung et al. 2000).

The regional differences in HIF- $1 \alpha$ may be explained by structural differences in these tissues, such as differences in vascularisation, or due do tissue specific differences in gene expression. It is interesting to note that the further in the circulation an organ was from the placenta the higher HIF- $1 \alpha$ mRNA levels were. It is possible that this pattern of expression reflects a progressive decrease in $\mathrm{O}_{2}$ tension as oxygenated blood travels from the placenta around the fetus.

Assuming that the Fe-restricted fetuses were not hypoxic, then why were they growth retarded? The decreased levels of lipids and amino acids in the Fedeficient fetuses could be causes of growth retardation as they provide both a rich source of energy and the building blocks for proteins. Decreased levels of the essential amino acids, phenylalanine and methionine, could be particularly detrimental to fetal growth. However, we cannot say that these factors do cause the fetal growth retardation and it is just as likely that the changes are a consequence of the growth retardation as its cause.

Fetal lipid is derived from a combination of endogenous synthesis and transfer of free fatty acids from the mother by facilitated diffusion across the placenta (Coleman, 1986; Stephenson et al. 1993). Thus, decreased fetal production, increased fetal demand or decreased placental transport could decrease fetal plasma triacylglycerol. Endogenous fetal production of lipids could be decreased by reduced activity of Fe-dependant enzymes. Studies in the rat adrenal gland have demonstrated decreased lipogenesis in the severely Fe-deficient anaemic rat (Sochor et al. 1982). Decreased liver weight in the Fe-restricted fetuses may contribute to their low plasma lipid levels although this would not explain the decreased maternal triacylglycerol in the 1-week group. The reduction in liver weight in the Ferestricted fetuses may also reflect decreased hepatic haemopoesis (Van Thiel et al. 1980).

As there were different effects on amino acids in the mother and fetus, the explanation for these changes is unlikely to be a direct effect of Fe deficiency on amino acid metabolism. Decreased levels of fetal plasma amino acids could also be due to increased fetal demand, either for protein synthesis or catabolism. As essential amino acids were decreased in the fetal plasma the decrease in fetal plasma amino acid levels cannot simply reflect decreased endogenous synthesis. The increased levels of amino acid in the maternal circulation may indicate that the mother is in a catabolic state. Alternatively, as amino acid transport is an active process, the enhanced feto-placental gradient may reflect a placental energy deficiency stemming from Fe-deficiency. Impaired maternal-fetal amino acid transport has been observed in other models of intrauterine growth retardation including maternal protein restriction and in the spontaneously hypertensive rat (Rosso, 1977; Lewis et al. 1998).

The increase in fetal plasma lactate in the Fe-restricted animals could indicate increased lactate production or that less of the lactate normally produced is being metabolised. Increased lactate is produced when oxidative metabolism is 
impaired. This is observed as a result of hypoxia, but could also occur if $\mathrm{Fe}$ deficiency was impairing oxidative metabolism. Moderate Fe deficiency does not greatly affect the activities of liver enzymes involved in the Krebs cycle, however the $\mathrm{Fe}$ deficiency in this model may be more severe (Stangl \& Kirchgessner, 1998b).

The present study demonstrates that maternal $\mathrm{Fe}$ restriction causes severe anaemia and fetal growth retardation. However, it does not support the hypothesis that anaemic hypoxia caused the fetal growth retardation in this model. Changes in fetal lipid and amino acid metabolism were observed which might contribute to the growth retardation. The reduction in levels of triacylglycerol and amino acids may be due to impaired placental transport or to metabolic abnormalities caused by Fe-deficiency.

\section{Acknowledgements}

We would like to thank A. Flack, A. Wayman and D. Hutt at the Dunn Nutrition Laboratories for expert technical assistance; Dr A. Healey at the Biochemical Genetic Diagnostic Unit in Peterborough for performing the amino acid assays; the Haematology Laboratories at Addenbrooke's Hospital for doing the haematology measurements; S. Shore from the Centre for Applied Medical Statistics, Department of Community Medicine, University of Cambridge, for advice on statistics. This work was funded by the Parthenon Foundation.

\section{References}

Bergeron M, Yu AY, Solway KE, Semenza GL \& Sharp FR (1999) Induction of hypoxia-inducible factor-1 (HIF-1) and its target genes following focal ischaemia in rat brain. European Journal of Neuroscience 11, 4159-4170.

Coleman RA (1986) Placental metabolism and transport of lipid. Federation Proceedings 45, 2519-2523.

Crowe C, Dandekar P, Fox M, Dhingra K, Bennet L \& Hanson MA (1995) The effects of anaemia on heart, placenta and body weight, and blood pressure in fetal and neonatal rats. Journal of Physiology 488, 515-519.

Davis LE \& Hohimer AR (1991) Hemodynamics and organ blood flow in fetal sheep subjected to chronic anemia. American Journal of Physiology 261, R1542-R1548.

Doughty IM \& Sibley CP (1995) Placental Transfer. In Fetal and Neonatal Physiology \& Clinical Applications, pp. 3-29 [MA Hanson, JAD Spencer and $\mathrm{CH}$ Rodeck, editors]. Cambridge: Cambridge University Press.

Felt BT \& Lozoff B (1996) Brain iron and behavior of rats are not normalized by treatment of Fe-deficiency anemia during early development. Journal of Nutrition 126, 693-701.

Forsythe JA, Jiang BH, Iyer NV, Agani F, Leung SW, Koos RD \& Semenza GL (1996) Activation of vascular endothelial growth factor gene transcription by hypoxia-inducible factor 1 . Molecular and Cellular Biology 16, 4604-4613.

Goldberg MA \& Schneider TJ (1994) Similarities between the oxygen-sensing mechanisms regulating the expression of vascular endothelial growth factor and erythropoietin. Journal of Biological Chemistry 269, 4355-4359.

Hebbel RP, Berger EM \& Eaton JW (1980) Effect of increased maternal hemoglobin oxygen affinity on fetal growth in the rat. Blood 55, 969-974.

Jung F, Palmer LA, Zhou N \& Johns RA (2000) Hypoxic regulation of inducible nitric oxide synthase via hypoxia inducible factor-1 in cardiac myocytes. Circulation Reseach 86, 319-325.

Law CM \& Shiell AW (1996) Is blood pressure inversely related to birth weight? The strength of evidence from a systematic review of the literature. Journal of Hypertension 14, 935-941.

Lewis RM, Bassett NS, Johnston BM \& Skinner SJ (1998) Fetal and placental glucose and amino acid uptake in the spontaneously hypertensive rat. Placenta 19, 403-408.

Lueder FL, Kim SB, Buroker CA, Bangalore SA \& Ogata ES (1995) Chronic maternal hypoxia retards fetal growth and increases glucose utilization of select fetal tissues in the rat. Metabolism 44, 532-537.

McCormick MC (1985) The contribution of low birth weight to infant mortality and childhood morbidity. New England Journal of Medicine 312, 82-90.

Mackler B, Grace R, Person R, Shepard TH \& Finch CA (1983) Iron deficiency in the rat: biochemical studies of fetal metabolism. Teratology 28, 103-107.

Mackler B, Person R, Miller LR \& Finch CA (1979) Iron deficiency in the rat: effects on phenylalanine metabolism. Pediatric Research 13, 1010-1011.

Martin C, Yu AY, Jiang BH, Davis L, Kimberly D, Hohimer AR \& Semenza GL (1998) Cardiac hypertrophy in chronically anemic fetal sheep: Increased vascularization is associated with increased myocardial expression of vascular endothelial growth factor and hypoxia-inducible factor 1. American Journal of Obstetrics and Gynecology 178, 527-534.

Rosso P (1977) Maternal-fetal exchange during protein malnutrition in the rat. Placental transfer of alpha-amino isobutyric acid. Journal of Nutrition 107, 2002-2005.

Semenza GL, Agani F, Booth G, Forsythe J, Iyer N, Jiang BH, Leung S, Roe R, Wiener C \& Yu A (1997) Structural and functional analysis of hypoxia-inducible factor 1. Kidney International 51, 553-555.

Shepard TH, Mackler B \& Finch CA (1980) Reproductive studies in the iron-deficient rat. Teratology 22, 329-334.

Singla PN, Tyagi M, Kumar A, Dash D \& Shankar R (1997) Fetal growth in maternal anaemia. Journal of Tropical Pediatrics 43, 89-92.

Sochor M, Baquer NZ \& McLean P (1982) Bio-inorganic regulation of pathways of carbohydrate and lipid metabolism. II. The effect of iron-deficiency on the profile of enzymes in the developing rat adrenal gland. Enzyme 27, 149-155.

Stangl GI \& Kirchgessner M (1998a) Different degrees of moderate iron deficiency modulate lipid metabolism of rats. Lipids 33, 889-895.

Stangl GI \& Kirchgessner M (1998b) Effect of different degrees of moderate iron deficiency on the activities of tricarboxylic acid cycle enzymes, and the cytochrome oxidase, and the iron, copper, and zinc concentrations in rat tissues. Zeitschrift fur Ernahrungswiss 37, 260-268.

Steer P, Alam MA, Wadsworth J \& Welch A (1995) Relation between maternal haemoglobin concentration and birth weight in different ethnic groups. British Medical Journal 310, 489491.

Stephenson T, Stammers J \& Hull D (1993) Placental transfer of free fatty acids: importance of fetal albumin concentration and acid-base status. Biology of the Neonate 63, 273-280.

van den Broek N (1998) Anaemia in pregnancy in developing countries. British Journal of Obstetrics and Gynaecology 105, 385-390.

Van Geijn HP, Kaylor WM Jr, Nicola KR \& Zuspan FP (1980) Induction of severe intrauterine growth retardation in the Sprague-Dawley rat. American Journal of Obstetrics and Gynecology 137, 43-47.

Van Thiel DH, Estes LW, Richey JE, Little JM \& Graham TO 
(1980) Fetal rat hepatic ultrastructural changes associated with organ culture and glucocorticoid treatment. Endocrinology 107, $557-565$.

Wiener CM, Booth G \& Semenza GL (1996) In vivo expression of mRNAs encoding hypoxia-inducible factor 1 . Biochemical and Biophysical Research Communications 225, 485-488.

Zhang J \& Byrne CD (1997) A novel highly reproducible quantitative competitve RT PCR system. Journal of Molecular Biology 274, 338-352.

Zhou LM, Yang WW, Hua JZ, Deng CQ \& Tao XStoltzfus RJ (1998) Relation of hemoglobin measured at different times in pregnancy to preterm birth and low birth weight in Shanghai, China. American Journal of Epidemiology 148, 998-1006. 